Bangladesh J. Plant Taxon. 17(2): 193-198, 2010 (December)

(C) 2010 Bangladesh Association of Plant Taxonomists

\title{
MARINE ALGAE OF ST. MARTIN'S ISLAND, BANGLADESH. IX. NEW RECORDS OF GREEN ALGAE (CHLOROPHYCEAE)
}

\author{
Abdul AzIZ1 ${ }^{1}$ Shahima Islam and Abdullah Harun Chowdhury ${ }^{2}$ \\ Department of Botany, University of Dhaka, Dhaka 1000, Bangladesh \\ Keywords: Cladophora crispula; Cladophora prolifera; Phyllodictyon anastomosans; St. Martin’s Island.
}

\begin{abstract}
Cladophora crispula Vickers, Cladophora prolifera (Roth) Kütz. and Phyllodictyon anastomosans (Harv.) Kraft et Wynne are recorded and described for the first time from the St. Martin’s Island, Cox's Bazar, Bangladesh.
\end{abstract}

\section{Introduction}

So far 45 taxa under 17 genera of green algae have been reported from Bangladesh coasts (Islam, 1964, 1965, 1973, 1976; Islam and Khair, 1978; Salam and Khan, 1980; Islam and Irfanullah, 2000; Aziz et al., 2008). The authors on examination of some preserved samples came across some green algae, which were not recorded earlier from the Bangladesh territory. These are described and illustrated in the present account.

\section{Materials and Methods}

Several marine algae collected from the littoral (exposed and knee-deep water below low tide mark) zone of St. Martin's Island, Cox's Bazar district Bangladesh on different occasions were preserved with $4 \%$ formalin in marine water. Cladophora prolifera (Roth) Kütz. was collected by Prof. Abdul Aziz, while Cladophora crispula Vickers and Phyllodictyon anastomosans (Harv.) Kraft et Wynne were collected by Dr. Abdullah Harun Chowdhury.

\section{Taxonomic enumeration}

Cladophora prolifera and Phyllodictyon anastomosans were found to be growing on exposed rocks, shells and stones while Cladophora crispula was found as an epiphyte on Phyllodictyon anastomosans collected from the coast of St. Martin's Island, Bangladesh. These taxa are new records for Bangladesh and are described and illustrated below.

\footnotetext{
${ }^{1}$ Corresponding author. E-mail: dr.aziz.botany@gmail.com

${ }^{2}$ Environmental Science Discipline, Khulna University, Khulna 9208, Bangladesh.
} 


\section{Class: Chlorophyceae; Order: Cladophorales; Family: Cladophoraceae Genus: Cladophora Kütz.}

\section{Cladophora crispula Vickers}

(Fig. 2 A-D)

(Taylor 1960, 85; Rios 1972, 227, 2: 8)

Plants filamentous, moderately branched, $3.00 \mathrm{~mm}$ high; thallus appears to be young, branching mainly monopodial; cells cylindrical, thallus attached by short finger-like rhizoidal extensions from the lower most cell; gradually broadened at the tip, slightly incurved, 248-362 $\mu \mathrm{m}$ long, diameter of broader region varies from 63.50 to $77.55 \mu \mathrm{m}$ and narrower region from 45.72 to $51.00 \mu \mathrm{m}$; tip cells $33.00-50.80 \mu \mathrm{m}$ broad with rounded apex; cell wall thick stratified, chloroplasts reticulate, with many small rounded to ovoid pyrenoides; reproductive structures not observed.
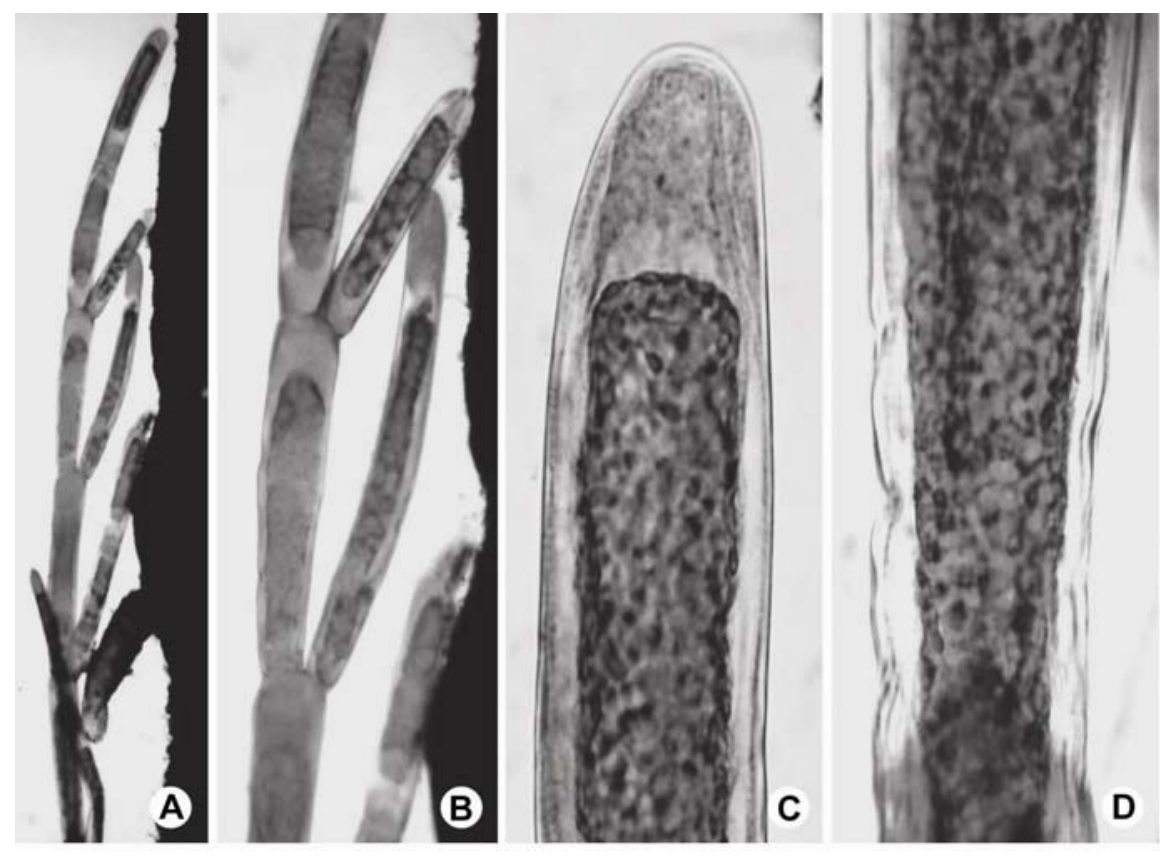

Fig. 1 A-D. Cladophora crispula Vickers. A. terminal part of a plant showing predominant unilateral branching; B. An enlarged portion of the plant; C. Apex of a terminal cell showing cell wall and chloroplast structures; D. Stratification of the cell wall and reticulate chloroplast in a median cell. Scales: A, $B=100 \mu \mathrm{m} ; C, D=25 \mu \mathrm{m}$.

Note: Islam (1976) reported Cladophora echinus (Biasoletto) Kütz. \& C. patentiramea (Montag.) Kütz. from St. Martin's Island, Bangladesh. The present material does not resemble with any of the above species. The present material resembles to a certain extent with C. gracilis (Griffiths) Kütz. by its branching pattern and cell shape but differs enormously by the size of the plant. The present material is very small (2.5-3.0 
$\mathrm{mm}$ long) compared to $30 \mathrm{~cm}$ for C. gracilis. However, the present material appears to be in early growing stage.

There are 1055 species names in the species database of Cladophora at present, of which 176 are flagged as currently accepted taxonomically. The two species recorded here are among the accepted ones.

Habitat and local distribution: Epiphytic on Phyllodictyon anastomosans; A.H. Chowdhury, 06 Jan. 2006, AHC 212.

Geographical distribution: Atlantic Islands: Bermuda; Caribbean Islands: Bahamas, Barbados, Cuba, Hispaniola; South Coast of Asia: Philippines, Vietnam (Taylor, 1960).

2. Cladophora prolifera (Roth) Kütz. [Conferva prolifera Roth]

(Fig. 1 A-D)

(Taylor 1960, 91, 3: 5; Joly 1965, 44, 3: 37, 4: 52)

Plants tufted, coarse and stiff, 5.0-5.6 cm high; thallus dark green, profusely branched, filaments up to $325 \mu \mathrm{m}$ broad near the base, with cells up to $1.75 \mathrm{~mm}$ long, small rhizoidal extensions from most of the cell bases, branching chiefly opposite, the branches rather erect, clustered toward the tip; branchlets lateral, not spreading, 125-150 $\mu \mathrm{m}$ broad and the cells $450-500 \mu \mathrm{m}$ long, tip cells blunt, cell wall very thick, stratified; chloroplast reticulate with numerous pyrenoids; reproductive structures were not observed.

Note: Present material differs from other marine species of Cladophora chiefly by predominant opposite branching and rhizoidal extension from cell base. This species differs from C. aokii Yamada by less rhizoidal investment on the main axes. Islam and Hossain (1978) reported Cladophora prolifera from a freshwater body of Dhaka city, about $1 \mathrm{~cm}$ high where cells in the middle part of the thallus are typically Cladophoralike, while cells in the apical part are globose to irregular shaped (probably zoosporangia). The size of the plant and variations in cell shape described by Islam and Hossain (1978) do not fit with the present material collected from lower intertidal zone and that of the illustrations and descriptions for species from marine habitat (Newton, 1931; Taylor, 1957, 1960). Thus, it appears that the material described by Islam and Hossain is wrongly identified (that needs to be amended), and by mistake the species has been quoted as marine in Ahmed et al. (2008). Thus, C. prolifera described here is a new record for Bangladesh.

Habitat and local distribution: Plants commonly grow on rocks and stones; Abdul Aziz, 01 March, 1995; AA 9.

Geographical distribution: Cosmopolitan in temperate and tropical zones occurring in brackish and marine conditions (Taylor, 1960). 


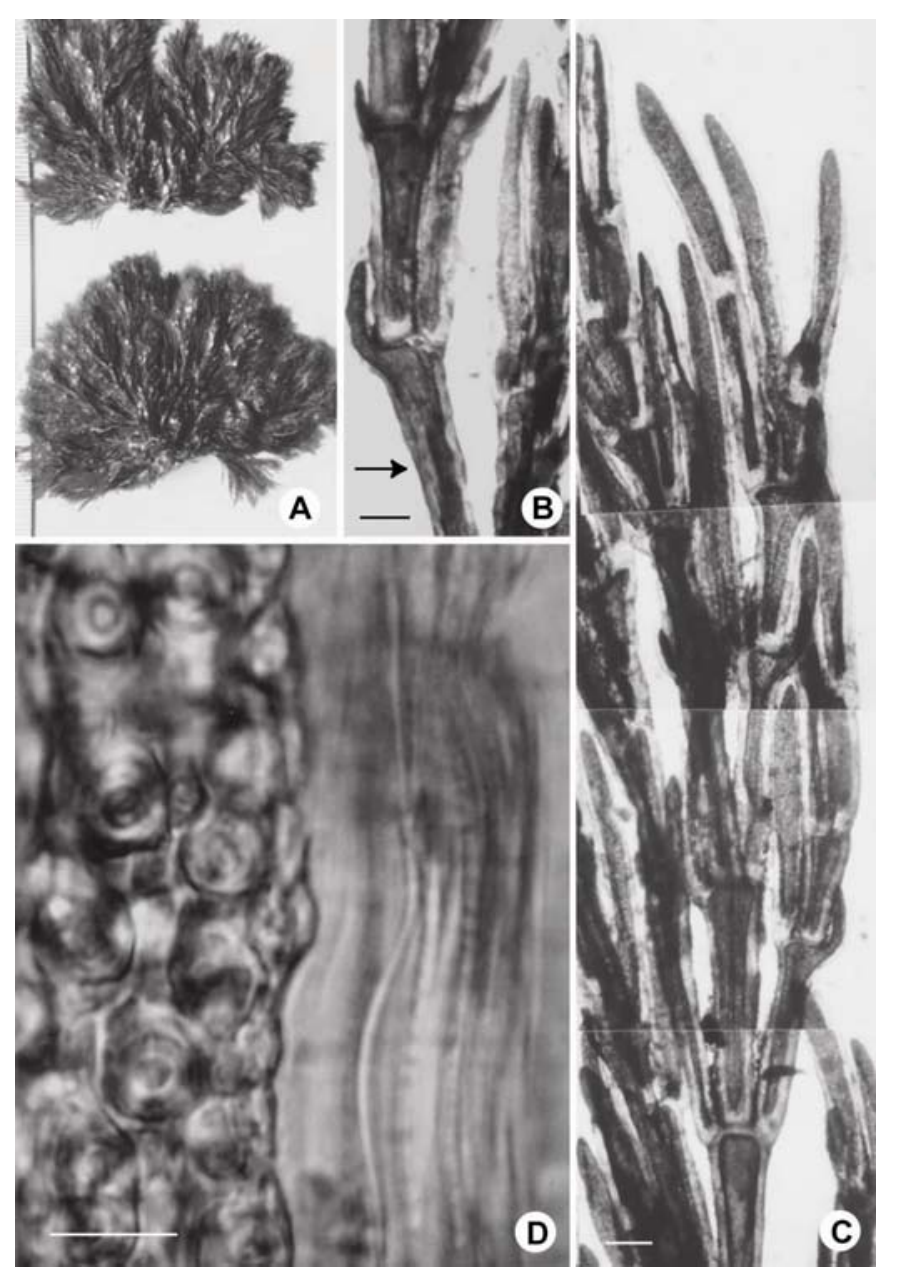

Fig. 2. A-D. Cladophora prolifera (Roth) Kütz. A. Habit of plants; B. Rhizoidal extension from the base of branches (arrow); C. Upper portion of a main axis showing branching habit; D. A portion of the cell showing heavily stratified cell wall and numerous pyrenoids. Scales: $B, C=100 \mu \mathrm{m} ; \mathrm{D}=25 \mu \mathrm{m}$.

\section{Class: Chlorophyceae; Order: Siphonocladales; Family: Boodleaceae Genus: Struvea Sonder.}

3. Phyllodictyon anastomosans (Harv.) Kraft et Wynne [Cladophora anastomosans Harv., Struvea anastomosans (Harv.) Picc., S. delicatula Kütz., (?) S. tenuis Zonard.]

(Fig. 3 A-E)

(Nizamuddin 1969, 239; Taylor 1960, 122, 9: 2, 5: 1 as Struvea anastomosans (Harv.) Picc.)

Plant densely entangled, filamentous, up to $1.0 \mathrm{~cm}$ tall, tufted distally; branching opposite, the main filamentous axes up to $372 \mu \mathrm{m}$ wide, unsegmented with constrict here and there $(6.50-16.00 \mathrm{~mm})$ in the lower part of the stalk but segmented above, bearing in 
a plane 4-6 pairs of opposite branchlet filaments which divide and redivide with decreasing regularity to form the net-work; in older filament cells are 1.6-4.5 mm long and $0.5 \mathrm{~mm}$ broad, in young filament cells are 200-400 $\mu \mathrm{m}$ long and 100-172 $\mu \mathrm{m}$ broad; young tip cells very curved 214-365 $\mu \mathrm{m}$ (outer face) and 175-285 $\mu \mathrm{m}$ (inner face) long. Cells are narrowest at the base and the diameter remains more or less same throughout most of its length and then swollen into a knee like structure at the tip, cell tip rounded. In the main filament, the lumen is narrowed to about $26 \mu \mathrm{m}$, in most part of the cell while in the most swollen part it is about $166 \mu \mathrm{m}$ broad; cell wall 25-30 layered; chloroplast reticulate; abundant growth of germlings found on the surface of old filament; reproductive structures were not observed.

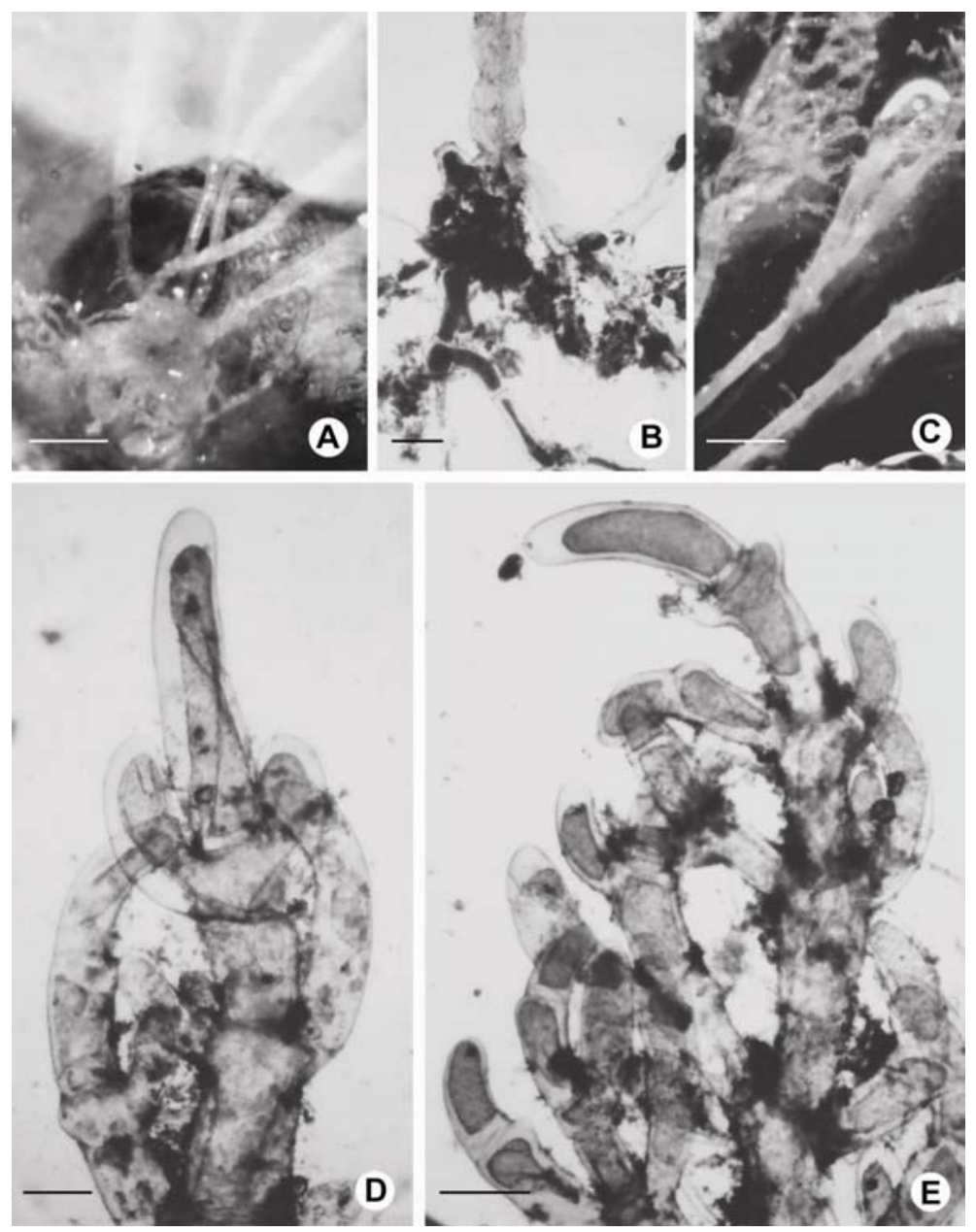

Fig. 3 A-E. Phyllodictyon anastomosans (Harv.) Kraft et Wynne. A. Basal portion of a plant. B. Enlarged part of the base showing constrictions in the axis and rhizoidal branches. C. Upper part of a plant with branches and branchlets. D. Apex of a developing branch. E. Part of a mature branch. Scales: A, C = $1 \mathrm{~cm}$; $\mathrm{B}=500 \mu \mathrm{m} ; \mathrm{D}, \mathrm{E}=200 \mu \mathrm{m}$. 
Note: There are 25 species names in the species database at present, of which 7 including the present species are flagged as currently accepted taxonomically. The genus is recorded for the first time from Bangladesh

Habitat and local distribution: The alga grows on rocks; A.H. Chowdhury, 06 Jan. 2006, AHC 212.

Geographical distribution: Atlantic Islands, Canary Islands, North America, Caribbean Islands, South America, Africa, Indian Ocean Islands, South-west Asia, Asia (Taylor, 1960).

\section{References}

Ahmed, Z.U., Begum, Z.N.T., Hassan, M.A., Khondker, M., Kabir, S.M.H., Ahmad, M., Ahmed, A.T.A., Rahman, A.K.A. and Haque, E.U. (Eds). 2008. Encyclopedia of Flora and Fauna of Bangladesh. Vol. 3. Algae, Chlorophyta (Aphanochaetaceae-Zygnemataceae). Asiatic Society of Bangladesh, Dhaka, 812 pp.

Aziz, A., Islam, S. and Alfasane, M.A. 2008. Ulva lactuca Lin. var. rigida (C. Ag.) Le Jolis (Chlorophyceae) from Inani Beach, Cox’s Bazar, Bangladesh. Bangladesh J. NOAMI 26(2): 87-89.

Islam, A.K.M.N. 1964. The genus Cladophorella newly found in East Pakistan. Rev. Alg. 7(4): 275-289.

Islam, A.K.M.N. 1965. Taxonomic study of species of Dichotomosiphon \& Vaucheria found in East Pakistan. Proc. Pak. Acad. Sci. 2(1): 47-56+9 pls.

Islam, A.K.M.N. 1973. A new species of Boodleopsis (Chlorophyta) from Bangladesh. Bangladesh J. Bot. 2(1): 53-67.

Islam, A.K.M.N. 1976. Contribution to the study of the marine algae of Bangladesh. Bibliotheca Phycologica 19: 1-253.

Islam, A.K.M.N. and Hossain, S.K.T. 1978. Algal flora of the ablution tanks of mosques in Dhaka city. J. Asiat. Soc. Bangladesh (Sci.) 3(2): 103-113.

Islam, A.K.M.N. and Irfanullah, H.M. 2000. Addition to the list of marine algae St. Martin's Island. VI. Codium Stackhouse. Bangladesh J. Plant Taxon. 7(2): 21-26.

Islam, A.K.M.N. and Khair, A. 1978. Addition to the list of marine algae of St. Martin's Island. I. Genus Codium Stackhouse. J. Asiat. Soc. Bangladesh (Sci) 4(1): 123-126.

Joly, A.B. 1965. Flora marinha do littoral norte do estado de Sao Paulo e Regioes circunvizinhas. Boletin No. 294. Fac. Fil. Cienc. e letr. Univ. Sáo Paulo, Bot. 21: 1-393.

Newton, L. 1931. A handbook of the british seaweeds. British Museum, London, 478 pp.

Nizamuddin, M. 1969. Contribution to the marine algae from West Pakistan. 1. Morphology and ecology of siphoneous algae. Algologique 3: 239-274.

Rios, N.R.de. 1972. Contribucion al estudio systematico de las algas macroscopicas De las costas de Venezuela. Acta Botánica Venezuelica. 7(1-4): 219-324 + 42 Lám with 85 figs.

Salam, A.M.A. and Khan, A.S.Y. 1980. Ulva patengansis, a new species from Bangladesh. Phykos 19(2): 129-131.

Taylor, R.W. 1957. Marine algae of the northeastern coast of North America. Univ. Mich. Press, Ann Arbor, 509 pp.

Taylor, R.W. 1960. Marine algae of the eastern tropical \& subtropical coasts of the America. Univ. Mich. Press, Ann Arbor, 870 pp. 